\title{
Nail Loss, CTCAE
}

National Cancer Institute

\section{Source}

National Cancer Institute. Nail LosS, CT CAE. NCI Thesaurus. Code C143696.

A disorder characterized by loss of all or a portion of the nail. 